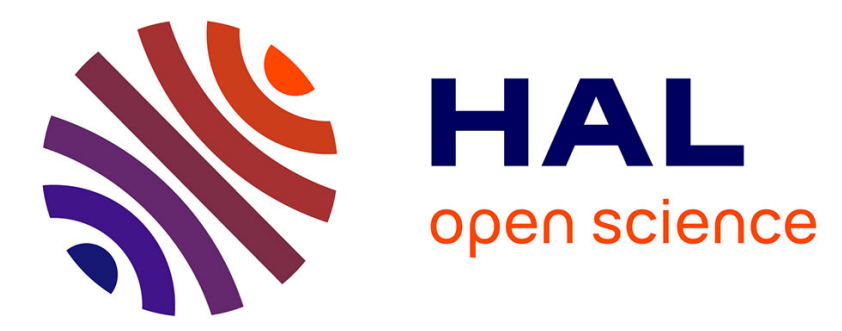

\title{
Development of Lead-210 Measurement in Peat Using Polonium Extraction. A Procedural Comparison
}

\author{
François de Vleeschouwer, Jaroslaw Sikorski, Nathalie Fagel
}

\section{To cite this version:}

François de Vleeschouwer, Jaroslaw Sikorski, Nathalie Fagel. Development of Lead-210 Measurement in Peat Using Polonium Extraction. A Procedural Comparison. Geochronometria, 2010, vol. 36, pp. 1-8. 10.2478/v10003-010-0013-5 . hal-00987195

\section{HAL Id: hal-00987195 https://hal.science/hal-00987195}

Submitted on 5 May 2014

HAL is a multi-disciplinary open access archive for the deposit and dissemination of scientific research documents, whether they are published or not. The documents may come from teaching and research institutions in France or abroad, or from public or private research centers.
L'archive ouverte pluridisciplinaire HAL, est destinée au dépôt et à la diffusion de documents scientifiques de niveau recherche, publiés ou non, émanant des établissements d'enseignement et de recherche français ou étrangers, des laboratoires publics ou privés. 


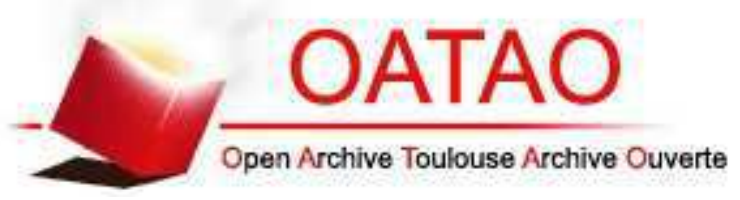

\section{Open Archive TOULOUSE Archive Ouverte (OATAO)}

OATAO is an open access repository that collects the work of Toulouse researchers and makes it freely available over the web where possible.

This is an author-deposited version published in : http://oatao.univ-toulouse.fr/ Eprints ID : 11505

To link to this article : doi:10.2478/v10003-010-0013-5

URL : http://dx.doi.org/10.2478/v10003-010-0013-5

To cite this version : De Vleeschouwer, François and Sikorski, Jarosław and Fagel, Nathalie Development of Lead-210 Measurement in Peat Using Polonium Extraction. A Procedural Comparison. (2010) Geochronometria, vol. 36 . pp. 1-8. ISSN 1733-8387

Any correspondance concerning this service should be sent to the repository administrator: staff-oatao@ listes-diff.inp-toulouse.fr 


\title{
DEVELOPMENT OF LEAD-210 MEASUREMENT IN PEAT USING POLONIUM EXTRACTION. A PROCEDURAL COMPARISON
}

\author{
FRANCOIS DE VLEESCHOUWER ${ }^{1 *}$, JAROSŁAW SIKORSKI ${ }^{1}$ and NATHALIE FAGEL ${ }^{2}$ \\ ${ }^{1}$ Silesian University of Technology, Institute of Physics, Department of Radioisotopes, GADAM Centre of Excellence, \\ Krzywoustego 2, 44-100 Gliwice, Poland \\ ${ }^{2}$ Argiles, Géochimie et Environnements Sédimentaires, Department of Geology, University of Liège, \\ Allée du 6 Août, B18, Sart Tilman, 4000 Liège, Belgium \\ *Now at: Department of Ecology and Environmental Science, Umeå University, SE-90187, Umeå, Sweden
}

\begin{abstract}
Two chemical treatments for lead-210 measurement were compared on the sub-surface samples of a core from an ombrotrophic bog from East Belgium. The classical procedure involves a concentrated acid extraction of polonium. However, this treatment represents substantial health risks together with unknowns regarding both the degree of cleanliness and the Po extraction rate, and most importantly, is rather time consuming. We developed here an improved procedure involving an ashing step prior to acid extraction. This allows substantial improvements such as: $1 /$ the use of a relatively small amount of acid compared to the classical procedure and $2 /$ the substantial reduction of a total sample digestion time. Measurements of ${ }^{210} \mathrm{~Pb}$ concentrations were conducted by alpha spectrometry. Results show a good agreement of unsupported ${ }^{210} \mathrm{~Pb}$ activity obtained for both procedures, although some unknowns remain concerning the adsorption of ${ }^{210} \mathrm{Po}$ on the plastic test tube, the volatilization of a small amount of ash, or the absorption of alpha particle at the alpha source surface. This however should not affect the ${ }^{210} \mathrm{~Pb}$ measurement as all the samples are spiked prior to ashing (i.e. the recoveries are fully monitored). Through this study, we are suggesting researchers to follow this new procedure in order to increase safety, cleanliness, better recovery and substantial time gain.
\end{abstract}

Keywords: ${ }^{210} \mathrm{~Pb}$, polonium, ashing, peat bog, recent sediment deposits.

\section{INTRODUCTION}

The phenomenon of radioactive disequilibrium is frequently used in geochronological studies. In particular, ${ }^{210} \mathrm{~Pb}$ is often used in order to provide a chronological framework in young sediments (i.e. not more than 150-200 years). Lead-210 originates mainly from the decay of ${ }^{222} \mathrm{Rn}$ present in the atmosphere (Turekian et al., 1977; Robbins, 1978). Lead-210 binds to the surface layer of aerosols. These aerosols are deposited at the Earth's surface and therefore increase the initial (e.g. supported) ${ }^{210} \mathrm{~Pb}$ content of the sediment, leading to a radioactive disequilibrium. As time goes on, aerosols are progressively buried into the sediment, and therefore cut off from the atmospheric (i.e. unsupported) ${ }^{210} \mathrm{~Pb}$ supply. This burial leads to the decay of the unsupported ${ }^{210} \mathrm{~Pb}$, rendering possible the reconstruction of a decay curve using the radioactive equation of ${ }^{210} \mathrm{~Pb}$. The half-

Corresponding author: F. De Vleeschouwer

e-mail: fdevleeschouwer@gmail.com life of ${ }^{210} \mathrm{~Pb}$ is $c a .22 .3$ years (e.g. Appleby, 2001; Carroll and Lerche, 2003). Therefore, the lowest theoretical measurement of unsupported ${ }^{210} \mathrm{~Pb}$ being around 9 halflives, the age of the oldest sediment that can be dated will average around 200 years. However, the measurement of ${ }^{210} \mathrm{~Pb}$ is often limited to younger samples, mainly because of the quality of analyses, and the background levels obtained in each specific laboratory. For example, Appleby (2001) reported a practical limit averaging around 150 years, but also reported that this age can be reduced towards ca. 130 years if the initial excess ${ }^{210} \mathrm{~Pb}$ surface activity is low $\left(<200 \mathrm{~Bq} \mathrm{~kg}^{-1}\right)$, which may be the case in peat records (see also tab. 1). Lead-210 was initially used in the determination of glacier accumulation, the assessment of environment changes and the age-dating of various sediments (e.g. Appleby and Oldfield, 1978; Krishnaswami, 1971; Tobin and Schell, 1988; Sikorski, 2003; Ebaid and Khater, 2006). At present, ${ }^{210} \mathrm{~Pb}$ is still abundantly used to date lake sediments (e.g. Luque and Julià, 2002; Xiang et al., 2002; Gąsiorowski and Hercman, 2003; Tylman, 2003; Erlinger et al., 2008) and more 
recently in organic soils (Klaminder et al., 2009). In peat bogs, the technique proved to be very efficient to provide an accurate control of the sub-surface peat layers, provided that the peat is ombrotrophic, i.e. exclusively fed by atmospheric inputs (e.g. Appleby et al., 1997; Shotyk et al., 1998; Le Roux et al., 2005; De Vleeschouwer et al., 2007; Novak et al., 2008; Olid et al., 2008). Ombrotrophic peat bogs are indeed able to trap any particle coming from the atmosphere. Their high acidity $(\mathrm{pH}$ around 3.5) and anoxic condition provide the ideal environment to preserve mineral micro-particles such aerosols, leading to the accumulation of the externally supplied unsupported ${ }^{210} \mathrm{~Pb}$. Since the middle eighties, ombrotrophic peat bogs have been dated using ${ }^{210} \mathrm{~Pb}$ in various locations in the world (e.g. Holynska et al., 1998; Shotyk et al., 1998; Turetsky et al., 2004; Le Roux et al., 2005; Mizugaki et al., 2006; De Vleeschouwer et al., 2007; Ali et al., 2008; Lamentowicz et al., 2008; Novak et al., 2008; Olid et al., 2008; De Vleeschouwer et al., 2009), mainly using a Constant Rate of Supply (CRS) model first developed by Appleby and Oldfield (1978). In terms of environmental reconstruction in peat bogs, several studies have, for example, showed that combined with elemental geochemistry and non radioactive lead isotopes, ${ }^{210} \mathrm{~Pb}$ was a powerful technique to evidence the industrial revolution through Europe, as well as the introduction of unleaded gasoline (e.g. Shotyk et al., 1998; De Vleeschouwer et al., 2007). Others have shown recent vegetation change (e.g. De Vleeschouwer et al., 2009; Lamentowicz et al., 2009).

Lead-210 measurements can be achieved by either directly using low background gamma spectrometry, or by measuring its decay product $\left({ }^{210} \mathrm{Po}\right)$ by alpha spectrometry. Despite having been proven efficient for low-density samples (e.g. peat, lake sediment), gamma spectrometry is limited in small samples (e.g. Ebaid and Khater, 2006) where the measurement of low-energy ${ }^{210} \mathrm{~Pb}$ gamma photons $\left(E_{210 P b}=46.5 \mathrm{keV}\right)$ is virtually impossible. Moreover, low background and high resolution gamma spectrometers are rather expensive compared to alpha spectrometers. Therefore, for low-activity samples, alpha spectrometry is preferred as the activity of ${ }^{210} \mathrm{~Pb}$ can be determined indirectly through the measurement of its decay product ${ }^{210}$ Po. However, ${ }^{210}$ Po needs to be chemically extracted from the material. In order to determine the extraction recovery, each sample also needs to be spiked with a known amount of ${ }^{208} \mathrm{Po}$, which has the same chemical properties as ${ }^{210} \mathrm{Po}$ but emitted alpha particles of a different energy.

At the Gliwice Absolute Dating Method Centre (Gliwice, Poland), the common procedure used is alpha spectrometry after polonium extraction using and incomplete $\mathrm{HNO}_{3}$ digestion (e.g. Sikorski, 2003; Sikorski and Bluszcz, 2008). However, Po activity in peat is relatively low, due to high peat accumulation rate $(\geq 1 \mathrm{~mm} /$ year or more) and the low content of aerosols per volume of peat, a material being almost exclusively composed of organic matter. A second difficulty resides in the fact that Po needs to be extracted from an organic matrix, which is still challenging due to its low dissolution rate, even in strong acids. However, most of studies have been using the extraction of Po from wet or dry sediment (e.g.
Holynska et al., 1998; Olid et al., 2008). Several alternative procedures were summarized by El-Daoushy et al. (1991, and reference therein). Their concluding remarks were that the radiochemical procedures needed to be optimized to achieve accurate analyses, especially at low ${ }^{210} \mathrm{~Pb}$ concentrations and small sample size. The type, size and composition of deposits analyzed are also crucial parameters needing to be checked and optimized. However, most of these procedures still involve either high amount of strong acids (leading to potential health hazards) or relatively time-consuming and complex procedures (i.e. involving a substantial amount of laboratory steps) leading to possible reproducibility problems. A step that has, to our knowledge, never been systematically investigated or applied is the calcination of the ${ }^{208}$ Po-spiked sample prior to Po extraction (e.g. protocols reported in Figgins, 1961; Edgington and Robbins, 1975; and Ebaid and Khater, 2006), despite its recent application for Po measurement (Fiałkiewicz-Kozieł, 2009). This lack of investigation is mainly due to the fact that Po may volatilize at relatively low temperature. However, no fractionation is expected during volatilization allowing further measurement of ${ }^{210} \mathrm{Po}$. Moreover, this ashing step greatly facilitates the whole chemical treatment in the case of peat by removing the organic matter and therefore allowing for low acid quantities to be used to dissolve the small remaining ash residue (1-5\% of the total dry mass).

In this paper, we present a comparison of Po extraction with and without ashing. The recent peat layers of a peat bog from Eastern Belgium were measured using both protocols. The extraction rate is compared together with the activity spectra and the absolute activities after one and two days of measurement per sample. It is obvious that the classical procedure involving chemical extraction has been used in numerous laboratories performing ${ }^{210} \mathrm{~Pb}$ measurements. Therefore, this article aims not to report a well-known procedure, but to emphasize some simple improvements in terms of safety, cleanliness, time consumption and possible extraction improvements.

\section{SITE DESCRIPTION}

The Misten bog is located in the Hautes-Fagnes Plateau (East Belgium, Fig. 1). This plateau displays several peat infillings, part of which are ombrotrophic peat bogs. The Misten bog is among the thickest peat deposit of this area, with more than $8 \mathrm{~m}$ of peat in its centre (Fig. 1). Previous studies have already demonstrated its great potential for past environmental reconstruction (De Vleeschouwer et al., 2007; Persh, 1950).

\section{CORING AND SUBSAMPLING}

As this work was carried out within the framework of other ongoing projects needing long sequences, it was decided to core the bog where the thickest peat sequence would be found. The upper meter was retrieved using the titanium Wardenaar corer (Wardenaar, 1987) of $1 \mathrm{~m}$ length and 15 by $15 \mathrm{~cm}$ section from the Institute for Environmental Geochemistry (University of Heidelberg, Germany). This type of corer enables to retrieve the softer upper parts of the peat, mainly composed of poorly 


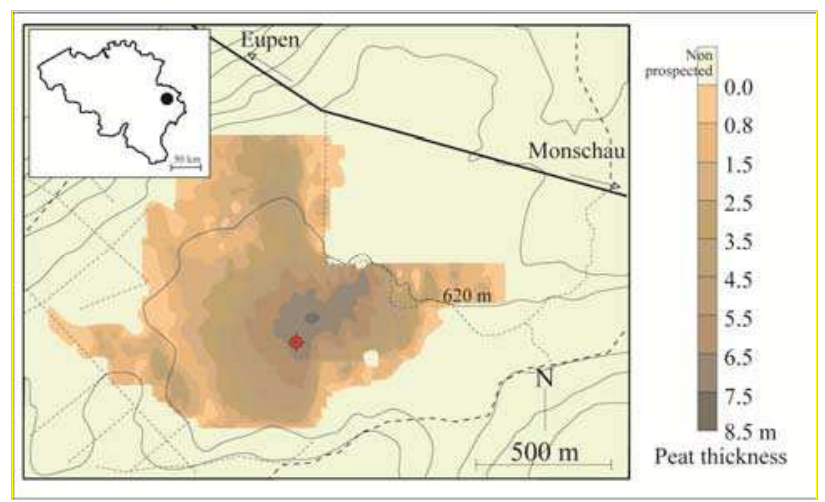

Fig. 1. The Misten bog and the location of the coring. Peat thickness after Wastiaux and Schumacker (2003). Dashed line represents pedestrian trails.

decomposed plant remains, that could be compressed using a Bielo-Russian corer (Belokopytov and Beresnevitch, 1955). The Wardenaar core was frozen and cut using a band saw at the Institute for Environmental Geochemistry (University of Heidelberg, Germany). Each sample was controlled for its thickness in order to assess the loss of material during the cutting. In this paper, we will only present the results concerning the ${ }^{210} \mathrm{~Pb}$ measurements on the topmost samples $(0-30 \mathrm{~cm})$ and on two bottom samples $(97-99 \mathrm{~cm}$, see Table 1 and 2).

\section{PRINCIPLES}

\section{Lead-210 formation and deposition}

In a peat bog, ${ }^{210} \mathrm{~Pb}$ has two sources (Oldfield and Appleby, 1984). The supported ${ }^{210} \mathrm{~Pb}$ is produced by the in situ decay of $\mathrm{U}$ contained in mineral grains trapped in the peat bog (Fig. 2). The decay of supported ${ }^{210} \mathrm{~Pb}$ will be continuously compensated by the continuous uranium decay, leading to a constant concentration of supported ${ }^{210} \mathrm{~Pb}$ along the peat profile. The unsupported ${ }^{210} \mathrm{~Pb}$ is created by the decay of ${ }^{222} \mathrm{Rn}$ in the atmosphere. It is adsorbed on aerosols that are further deposited and preserved in the peat bog. Wet or dry deposition is possible. Wet deposition occurs during precipitation, when aerosols serve as nuclei for the condensation of water vapour. Aerosols are also frequently washed out mechanically from the air. Dry deposition results of the gravitational fall of aerosols, or is due to air masses movement towards the surface of the peat bog (Vile et al., 1999; MartinezCortizas et al., 2002). The aerosols will eventually be buried in the peat, leading to the slow decay of unsupported lead according to its radioactive decay law.

\section{Sample preparation}

\section{The classical procedure}

The classical procedure used in most of the laboratories to extract the polonium from the sample is the digestion of the sample powder into concentrated $\mathrm{HNO}_{3}$ (e.g. Flynn, 1968). In our case, $0.5 \mathrm{~g}$ of dry peat powder spiked with $1 \mathrm{ml}$ of ${ }^{208} \mathrm{Po}$ (same chemical properties than ${ }^{210} \mathrm{Po}$ but different alpha particle energy) was digested with
$20 \mathrm{ml}$ of concentrated $\mathrm{HNO}_{3}$ (Fig. 2). The spike consists in diluted $\mathrm{HCl} 0,05 \mathrm{M}$ containing a known amount of certified ${ }^{208}$ Po (manufactured by AERE Harwell, United Kingdom) which specific activity is $3 \mathrm{~Bq} \mathrm{~g}^{-1}$.

However, in the case of peat, the high content of organic matter renders this extraction challenging. Indeed, the reaction of organic matter with $\mathrm{HNO}_{3}$ is strongly exothermic and causes a lot of degassing, leading to potential health hazards. Usually, to avoid this problem, the reaction is achieved in a Teflon beaker sealed in a metallic bomb and heated at $105^{\circ} \mathrm{C}$ for 12 hours. However, the reaction is still incomplete as a lot of organic matter is not digested and needs to be centrifuged ( $3500 \mathrm{rpm}, 20 \mathrm{~min}$.) afterwards. After this step, the liquid residue is transferred in a Teflon beaker where $30 \mathrm{ml}$ of $\mathrm{H}_{2} \mathrm{O}_{2}$ is added to oxygenate the organic matter during 12 hours. Again, the reaction of $\mathrm{H}_{2} \mathrm{O}_{2}$ with dissolved organic matter is strongly exothermic, leading to potential over-leaking of the sample out of the beaker. Then the liquid is evaporated and $20 \mathrm{ml}$ of concentrated $\mathrm{HCl}$ is added and evaporated. This operation is repeated twice to guarantee the total removal of $\mathrm{HNO}_{3}$. The sample is then dissolved in diluted $50 \mathrm{ml}$ $\mathrm{HCl}$ together with $40 \mathrm{mg}$ of hydroxylamine hydrochloride and $40 \mathrm{mg}$ of tri-sodium citrate dihydrate. The solution is heated and stirred on a magnetic stirrer and the deposition is achieved on a silver disc dipped into the liquid for $c a$. 3 hours. This last step is again crucial as other oxidants such as organic matter may bind to the silver disc despite the use of hydroxylamine hydrochloride and tri-sodium citrate dihydrate (El-Daoushy et al., 1991 and reference therein). It is therefore important to entirely remove the organic fraction of the sample. This is not achieved using the classical procedure but can be achieved by ashing the sample.

The overall extraction procedure takes 3 days per sample (as generally, one sample is processed at one time) and is relatively efficient. However, there are nonnegligible health hazards due to the high amount of concentrated acids used during the extraction $\left(20 \mathrm{ml} \mathrm{HNO}_{3}\right.$ and $40 \mathrm{ml} \mathrm{HCl}$ ) but also to the degassing and potential over-leaking of the sample. Moreover, the latter problem can cause the loss of a part of the sample, leading to problems in the measurement and repeated extraction for the same sample. Finally, the overall extraction is not of the

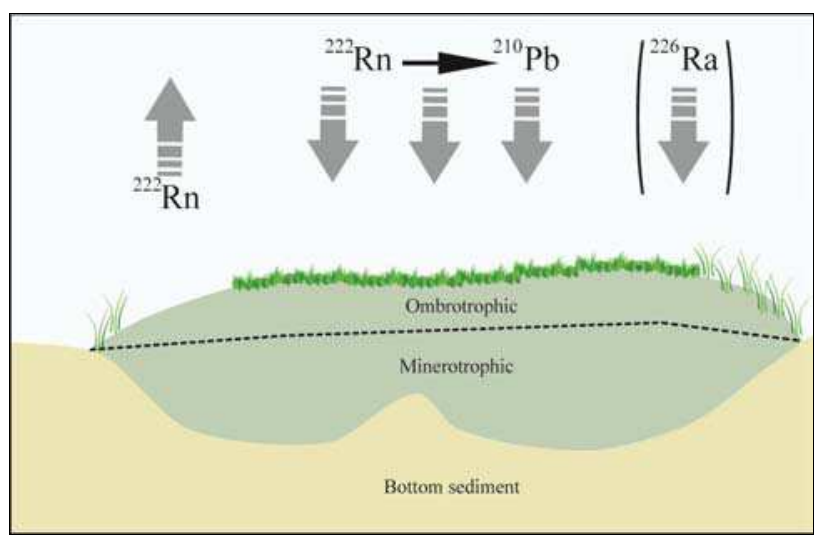

Fig. 2. The sources of lead-210 in a peat bog (after Robbins, 1978; Goslar et al., 2000). 
Table 1. One- and several days ("more": 1-2 days more) total ${ }^{210} \mathrm{~Pb}$ activity measurements using the classical and ashing procedures. Some samples were not measured for both treatments due to the lack of material. Note that, using the ashing procedure, the overall recoveries are higher in 19 of the 27 samples measured after the extraction using both procedures. "Higher" and "lower" refer to the lower or higher recovery for the ashing procedure compared to the classical procedure.

\begin{tabular}{|c|c|c|c|c|c|c|c|c|c|}
\hline \multirow[b]{2}{*}{$\begin{array}{l}\text { Depth } \\
(\mathrm{cm})\end{array}$} & \multirow[b]{2}{*}{$\begin{array}{l}\text { Measured } \\
\text { days }\end{array}$} & \multicolumn{2}{|c|}{ Classical procedure } & \multicolumn{3}{|c|}{ Ashing procedure } & \multirow[b]{2}{*}{$\begin{array}{c}\text { Recovery } \\
(\%) \\
\end{array}$} & \multirow{2}{*}{\multicolumn{2}{|c|}{$\begin{array}{c}\text { Comparison of ast } \\
\text { classical proce- } \\
\text { dures } \\
(\%)\end{array}$}} \\
\hline & & $\begin{array}{c}\text { Total }{ }^{210} \mathrm{~Pb} \\
\text { activity } \\
(\mathrm{Bq} / \mathrm{kg}) \\
\end{array}$ & $\begin{array}{c}\text { Uncertainty on } \\
\text { total activity } \\
(\mathrm{Bq} / \mathrm{kg})\end{array}$ & $\begin{array}{c}\text { Recovery } \\
(\%) \\
\end{array}$ & $\begin{array}{c}\text { Total }{ }^{210} \mathrm{~Pb} \\
\text { activity } \\
(\mathrm{Bq} / \mathrm{kg}) \\
\end{array}$ & $\begin{array}{c}\text { Uncertainty on } \\
\text { total activity } \\
(\mathrm{Bq} / \mathrm{kg})\end{array}$ & & & \\
\hline 0.97 & 1 & - & - & - & 822 & 44 & 46 & - & - \\
\hline 2.64 & 1 & - & - & - & 808 & 38 & 62 & - & - \\
\hline 3.8 & 1 & - & - & - & 743 & 26 & 38 & - & - \\
\hline 4.86 & 1 & 752 & 23 & 31 & 719 & 30 & 24 & 23 & lower \\
\hline 4.86 & More & 730 & 19 & 32 & - & - & - & & \\
\hline 5.98 & 1 & 697 & 27 & 54 & 656 & 32 & 97 & 44 & higher \\
\hline 5.98 & More & 724 & 30 & 53 & - & - & - & - & - \\
\hline 7.19 & 1 & 659 & 18 & 33 & 610 & 33 & 45 & 27 & higher \\
\hline 8.45 & 1 & 632 & 25 & 27 & 612 & 23 & 69 & 61 & higher \\
\hline 8.45 & More & 661 & 27 & 28 & 625 & 19 & 71 & 61 & higher \\
\hline 9.72 & 1 & 897 & 44 & 91 & 542 & 21 & 51 & 44 & lower \\
\hline 9.72 & More & 871 & 41 & 88 & 539 & 17 & 51 & 42 & lower \\
\hline 11 & 1 & 558 & 22 & 51 & 485 & 13 & 69 & 26 & higher \\
\hline 11 & More & 547 & 18 & 54 & - & - & - & - & - \\
\hline 12.3 & 1 & 300 & 13 & 38 & 340 & 15 & 49 & 22 & higher \\
\hline 12.3 & More & 433 & 15 & 36 & 329 & 11 & 50 & 28 & higher \\
\hline 13.7 & 1 & 426 & 14 & 66 & 230.3 & 7.8 & 52 & 21 & lower \\
\hline 13.7 & More & 444 & 12 & 65 & - & - & - & - & - \\
\hline 15 & 1 & 432 & 20 & 19 & 125.5 & 5.6 & 42 & 55 & higher \\
\hline 16.3 & 1 & 175 & 6.3 & 17 & 187.3 & 6.9 & 25 & 32 & higher \\
\hline 17.5 & 1 & 44.7 & 2 & 33 & 27 & 5.1 & 78 & 58 & higher \\
\hline 17.5 & More & - & - & - & 31.2 & 3.2 & 75 & - & - \\
\hline 18.8 & 1 & 126.9 & 5.9 & 41 & 24.8 & 2.6 & 45 & 9 & higher \\
\hline 18.8 & More & - & - & - & 22.5 & 1.7 & 47 & & \\
\hline 20.2 & 1 & 75.8 & 5.7 & 43 & 59.4 & 2.9 & 74 & 42 & higher \\
\hline 20.2 & More & 77 & 3.8 & 45 & - & - & - & - & - \\
\hline 21.5 & 1 & 36.7 & 4.3 & 44 & 18.1 & 1.7 & 76 & 42 & higher \\
\hline 22.9 & 1 & 37.5 & 3.3 & 20 & 10.1 & 1.3 & 41 & 51 & higher \\
\hline 24.2 & 1 & 35.9 & 3.9 & 56 & 8.1 & 0.9 & 42 & 25 & lower \\
\hline 25.5 & 1 & 33.6 & 2.4 & 55 & 11.4 & 2.2 & 24 & 56 & lower \\
\hline 26.7 & 1 & 17.2 & 2 & 34 & 6.6 & 0.9 & 41 & 17 & higher \\
\hline 28.1 & 1 & 47.2 & 4 & 20 & 11 & 2.1 & 35 & 43 & higher \\
\hline 29.4 & 1 & 35.1 & 3.8 & 69 & 6.6 & 1.4 & 37 & 46 & lower \\
\hline 30.7 & 1 & 15 & 2.2 & 51 & 6 & 0.7 & 34 & 33 & lower \\
\hline 32 & 1 & 19 & 2.3 & 59 & 9.2 & 2.2 & 68 & 13 & higher \\
\hline 32 & More & - & - & - & 7.2 & 1.4 & 65 & - & - \\
\hline 96.4 & 1 & 18.3 & 1.9 & 35 & 30.8 & 4.7 & 44 & 20 & higher \\
\hline 97.9 & 1 & 14.1 & 1.3 & 32 & 29.3 & 4 & 69 & 54 & higher \\
\hline
\end{tabular}

cleanest procedure, leading to possible relatively important background and/or peak scatter. For these reasons, an alternative extraction (see $\S$ "The ashing procedure") was developed to circumvent the high organic matter content of the sample and the high amount of concentrated acids.

\section{The ashing procedure}

Half a gram of each dry sample powder was transferred in a $10 \mathrm{ml}$ plastic test tube, where $1 \mathrm{ml}$ of Po was added (Fig. 3). The tubes were closed for 24 hours in order to let the Po impregnate the peat powder. Afterwards, the tubes were opened and slowly evaporated (ca. $\left.60^{\circ} \mathrm{C}\right)$. The resulting dry powder was transferred in ceramic crucibles with caps and was combusted at $550^{\circ} \mathrm{C}$ for 4 hours in a muffle furnace. The resulting ash was transferred in $15 \mathrm{ml}$ Teflon beaker (Savilex). This transfer required high caution as: $1 /$ the amount of ash was very low ( $c a .1 \%$ of the initial dry powder) and $2 /$ the ash was very volatile. From this point, all the analytical procedure was performed in the class-100 workstations of the AGEs (ULg, Belgium). All the acids were Merck quality or equivalent, were sub-boiled twice and were of the highest concentration. Four millilitres of $\mathrm{HNO}_{3}$ was added to each beaker. The beakers were tightly closed and heated at $120^{\circ} \mathrm{C}$ for 24 hours. The liquid was evaporated and 2 $\mathrm{ml}$ of $\mathrm{HCl}$ was added. The beakers were tightly closed and heated at $120^{\circ} \mathrm{C}$ for 24 hours. Sometimes, a very few particles were remaining undigested. The samples were therefore put in ultrasonic bath for 20 minutes. If any particle remained after this step, the sample was transferred in an Ependorf $2.5 \mathrm{ml}$ microtube and centrifuged 


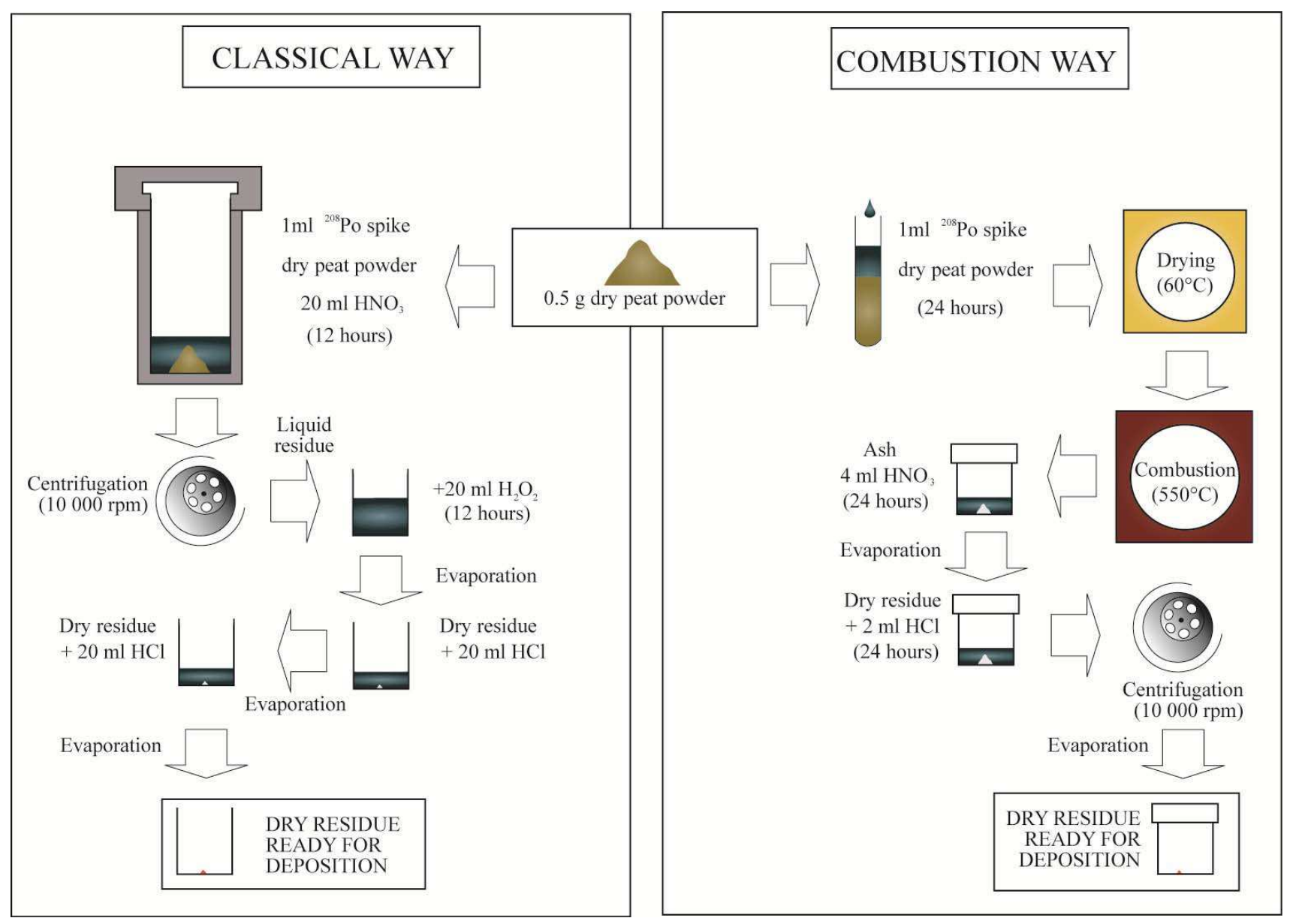

Fig. 3. Flowsheet summarizing the different steps of each extraction procedure. In the classical procedure, the extraction is always incomplete (i.e. there is a solid peat powder residue that need to be isolated), while in the ashing procedure, the digestion is full.

(7500 rpm, $20 \mathrm{~min}$.). The remaining liquid was transferred in a $7 \mathrm{ml}$ Teflon snap-cap beaker and evaporated. The dry residue was in the form of a very small orange bubble at the bottom of the beaker. The deposition of silver discs was achieved using the same procedure as for the classical procedure.

\section{Lead-210 measurement}

The total (i.e. supported and unsupported) activity of ${ }^{210} \mathrm{~Pb}$ was determined indirectly through the measurement of its decay product ${ }^{210} \mathrm{Po}$ using alpha spectrometry. The spectrometer was tuned to cover the energies emitted by alpha particles from ${ }^{210} \mathrm{Po}$. Alpha activity was measured with a spectrometer Canberra model 7401, with a surfacebarrier Si semiconductor detector. Sensitive area of the detector is $300 \mathrm{~mm}^{2}$ and its energy resolution is $c a .20$ $\mathrm{keV}$. This enabled a very good separation of peaks from ${ }^{210} \mathrm{Po}-\mathrm{E}=5.308 \mathrm{MeV}$ and ${ }^{208} \mathrm{Po}-\mathrm{E}=5.105 \mathrm{MeV}$ (Sikorski and Goslar, 2003). In order to assess the activity of supported ${ }^{210} \mathrm{~Pb}$, two deep samples (see Table 1 and 2) where unsupported ${ }^{210} \mathrm{~Pb}$ had decayed were analysed.

The amount of supported ${ }^{210} \mathrm{~Pb}$ in a peat bog depends mainly on the presence of mineral grains bearing elements from the uranium decay series. The Misten bog is located in an area which is surrounded by forests with dense bushes, which efficiently prevents the amount of local mineral grains to be transported to the bog. As a result there was a small concentration of supported ${ }^{210} \mathrm{~Pb}$ in the samples. Moreover, non-atmospheric inputs, as e.g. river inputs in lakes, are not likely as the bog is exclusively fed by atmospheric inputs.

The measurements were carried out on both classicaland ashing-processed samples. Moreover, in order to control the gain of recovery along time, all the samples

Table 2. Constant Rate of Supply age model (Appleby, 2001) applied on results obtained both by the classical and ashing procedures.

\begin{tabular}{ccccc}
\hline & \multicolumn{3}{c}{ Classical } & \multicolumn{3}{c}{ Ashing } \\
$\begin{array}{c}\text { Depth } \\
\text { (cm) }\end{array}$ & $\begin{array}{c}\text { Top Age } \\
\text { yr AD }\end{array}$ & $\begin{array}{c}\text { Uncertainty } \\
\text { yr }\end{array}$ & $\begin{array}{c}\text { Top Age } \\
\text { yr AD }\end{array}$ & $\begin{array}{c}\text { Uncertainty } \\
\text { yr }\end{array}$ \\
\hline 0.97 & 2006 & 2 & 2006 & 2 \\
2.64 & 2005 & 2 & 2005 & 2 \\
3.8 & 2004 & 2 & 2003 & 2 \\
4.86 & 2003 & 2 & 2002 & 2 \\
5.98 & 2003 & 2 & 2001 & 2 \\
7.19 & 2001 & 2 & 1999 & 2 \\
8.45 & 1998 & 2 & 1994 & 2 \\
9.72 & 1995 & 2 & 1990 & 2 \\
11 & 1985 & 2 & 1980 & 2 \\
12.3 & 1978 & 2 & 1969 & 3 \\
13.7 & 1967 & 3 & 1952 & 4 \\
15 & 1947 & 5 & 1930 & 5 \\
16.3 & 1901 & 6 & 1912 & 7 \\
17.5 & 1765 & 9 & 1745 & 9 \\
\hline
\end{tabular}


were measured one day, then 1-2 days more. The specific activity of ${ }^{210} \mathrm{~Pb}$ was determined using the Eq. 4.1. This formula makes allowance for short-lived isotopes decay and efficiency of chemical procedure and spectrometry measurement. The uncertainties on the specific and surface activities were estimated using the method of propagation of errors. The results are given in Table $\mathbf{1}$ and $\mathbf{2}$.

$$
A_{\text {total }}=\frac{I_{{ }_{210} P_{O}} A_{s} m_{s} e^{-\lambda_{208 P o} t_{1}} e^{\lambda_{210 P o} t_{2}}}{I_{208 P o} M}
$$

where:

$A_{\text {total }}-\left(\mathrm{Bq} \mathrm{kg}{ }^{-1}\right)$ specific activity of whole ${ }^{210} \mathrm{~Pb}$ (supported and unsupported) in measured sample (layer)

$I_{210 P o}-(\mathrm{cps})$ net counting rate of impulses in ${ }^{210}$ Po peak

$I_{208 P o}-(\mathrm{cps})$ net counting rate of impulses in ${ }^{208}$ Po peak

$A_{p s}-\left(\mathrm{Bq} \mathrm{kg}^{-1}\right)$ specific activity of ${ }^{208}$ Po standard sample

$\mathrm{m}_{\mathrm{s}}-(\mathrm{kg})$ mass of standard sample

$\lambda_{208 \mathrm{Po}}, \lambda_{210 \mathrm{Po}}-\left(\mathrm{s}^{-1}\right)$ decay constant for ${ }^{208} \mathrm{Po} \mathrm{i}^{210} \mathrm{Po}$

$t_{1}-(\mathrm{s})$ time from preparation of standard to half of measurement

$t_{2}-(\mathrm{s})$ time from deposition to half of measurement $M-(\mathrm{kg})$ dry mass of sample

The recovery is determined by comparing the activity measured in the standard with the one of the sample (spiked with a known amount of standard). The recovery ranges between $17 \%$ and $91 \%$ (mean $44 \%$ ) and between $24 \%$ and $97 \%$ (mean: $54 \%$ ) for the classical and the ashing procedures, respectively.

\section{DISCUSSION}

The raw (i.e. not modelled) data shows decreasing ${ }^{210} \mathrm{~Pb}$ specific activities with depth (Fig. 4). The data resulting from the one or several days of measurement are relatively similar for each pre-treatment (Table 1). The total ${ }^{210} \mathrm{~Pb}$ activity is however generally lower with the ashing procedure than with the classical one (Fig. 4). Possible reasons are the adsorption of ${ }^{210} \mathrm{Po}$ on the plastic test tube, the volatilization of a small amount of ash, or the absorption of alpha particle at the alpha source surface. The volatilisation of elemental lead or polonium may also be possible. In peat, $\mathrm{Pb}$ and $\mathrm{Po}$ are bound to trapped aerosols than being present as elements. The volatilization of such $\mathrm{Pb}$ - or Po-bearing particle is therefore questionable. A recent investigation dealing with lead isotopes extraction in a peat bog showed that $\mathrm{Pb}$ volatilisation is unlikely during the ashing (Kylander et al., 2004). Jia et al. (2001) also reported minimum effect of fusion on the ${ }^{210} \mathrm{~Pb}$ and ${ }^{210} \mathrm{Po}$ of rock and soil samples, which supports that the temperature should not be the factor provoking the loss in activity reported in the ashing of our samples. More recently, Jia and Torri (2007) reported that around $14 \%{ }^{210} \mathrm{Po}$ was volatilized when dust samples at $600^{\circ} \mathrm{C}$ but that the ashing time did not affect the rate of volatilization. In our case, the ashing temperature was rather similar $\left(550^{\circ} \mathrm{C}\right)$. Therefore, in our experiment, ${ }^{210} \mathrm{~Pb}$ volatilization is negligible and ${ }^{210} \mathrm{Po}$ volatilization is low. Further investigations should be carried out to better understand these discrepancies, which are however, not observed for unsupported lead. We therefore expect that the further age-modeling of these data will give similar pattern using the data from either the classical or the ashing procedure.

The profile obtained using the classical procedure displays two peaks around $10 \mathrm{~cm}$ and $15 \mathrm{~cm}$ (Fig. 4). So far these two peaks remained unexplained as periods of enhanced ${ }^{210} \mathrm{~Pb}$ activity and/or deposition should be recorded using both procedures. One possible cause of such high activities may be contamination during the extraction process as the classical procedure was performed in a laboratory that was not as Po- and $\mathrm{Pb}$-free as the clean air workstations used for the ashing procedure. We do however have no evidence so far to argument this hypothesis. Another possibility is external alpha particles disturbing signal during measurement. However, this does not question the reliability of the data, because the resulting CRSmodelled ages are very similar (Table 2).

The overall recoveries are greatly fluctuating from $17 \%$ to $91 \%$ and $24-97 \%$ using the classical and ashing procedures (Table 1), respectively. However, a pairedsamples T-test (SPSS 18.0.1 software) showed that recoveries after ashing are $9 \%$ to $61 \%$ significantly higher ( $\mathrm{p}$ (two-tailed) $<0.1)$ than using the classical procedure in more than $2 / 3$ of the samples. Therefore, together with its low need in acids the ashing procedure enhances the better safety and reliability of the procedure. Finally, besides giving a cleaner safer procedure, the ashing procedure provides a major improvement in the time needed to prepare the samples prior to measurement. Twenty samples can be digested in 2 days, instead of 1 sample per day using the classical procedure.

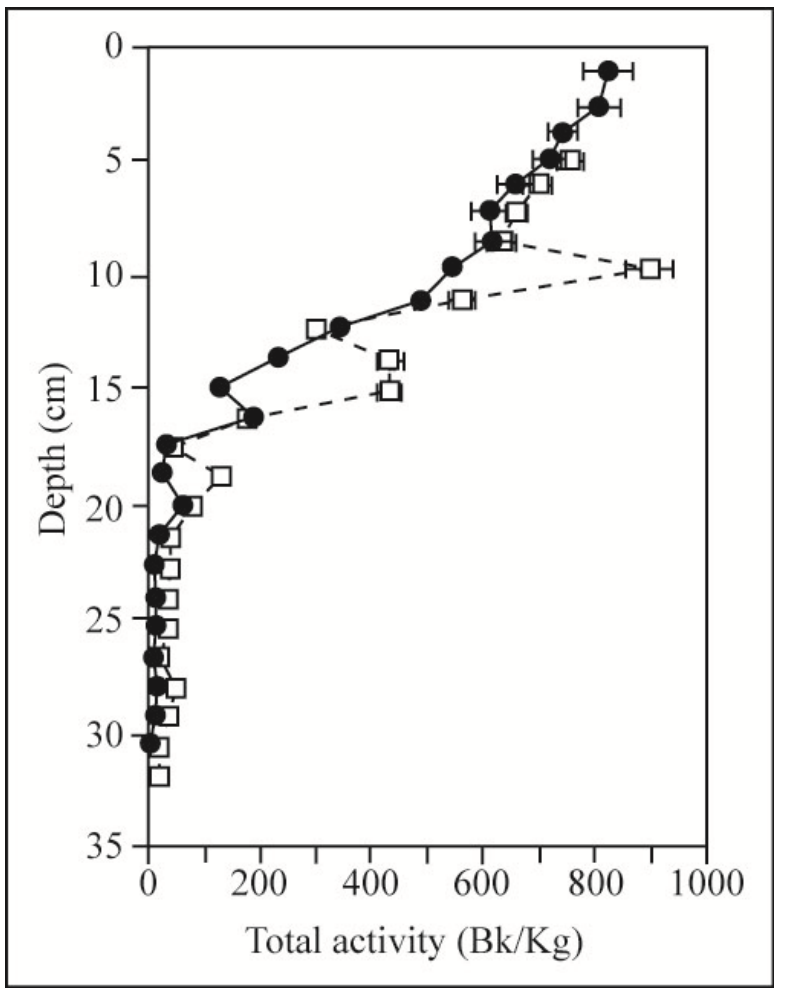

Fig. 4. Comparison between the total activity obtained on the Misten profile after several days of measurements using the classical procedure (open squares) and the ashing procedure (black circles). 
Table 3. Comparison of the two extraction procedures.

\begin{tabular}{|c|c|c|}
\hline & ADVANTAGES & DISADVANTAGES \\
\hline 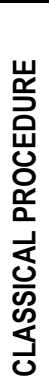 & $\begin{array}{c}\text { Low cost } \\
\text { No specific lab equipment needed }\end{array}$ & $\begin{array}{c}\text { High amount of concentrated acids (overall } 60 \mathrm{ml} \text { ) } \\
\text { Requires } \mathrm{H}_{2} \mathrm{O}_{2} \\
\text { Highly exothermic } \\
\text { High acid degassing } \\
\text { High risk of leaking (principally during } \mathrm{H}_{2} \mathrm{O}_{2} \text { reaction) } \\
\text { Non-negligible health hazard } \\
\text { Very slow (1 sample per days) }\end{array}$ \\
\hline 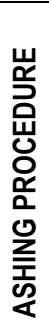 & 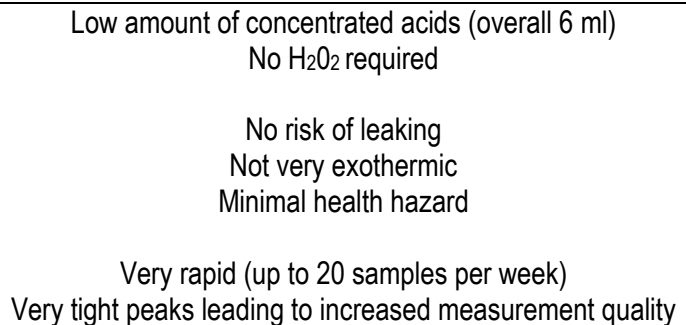 & $\begin{array}{l}\text { Possible risk of loss during ash transfer } \\
\text { Increased lab costs (high quality acid, clean lab) }\end{array}$ \\
\hline
\end{tabular}

\section{SUMMARY}

Two chemical pre-treatments for gamma measurement of ${ }^{210} \mathrm{~Pb}$ were compared for low-density peat samples. Advantages and disadvantages of the classical and the ashing procedures of Po extraction are listed in Table 3. The classical procedure used involves the chemical extraction of ${ }^{210} \mathrm{Po}$ using a large quantity of nitric acid. It leads to an incomplete digestion and therefore uncertainties concerning the extraction rate, but also to substantial chemical hazards. It is also time consuming. The main advantage of the ashing procedure is a 10time decrease in both the volume of concentrated acids needed and the pre-treatment time. This will lead to an overall safer procedure. Moreover, as no $\mathrm{H}_{2} \mathrm{O}_{2}$ is required, the risk of leaking is negligible. However, a possible source of loss of sample is the transfer of the very light and highly volatile ash in the Teflon beakers. The second important advantage is that the overall extraction uses a cleaner procedure, leading in a better quality in the Po measurements. Finally, the most direct advantage is that up to 20 samples can be extracted in one week, which increased by 10 times the laboratory turnover. The most direct disadvantage is of course the increased costs of such clean workstation. However, we are convinced that the sole ashing, the use of clean Teflon beakers and pro analisi acids will lead to a much better extraction compared to the use of the Teflon bomb and the dry peat without any ashing. Unsupported ${ }^{210} \mathrm{~Pb}$ activities are relatively similar for both pre-treatments promising to give similar age-models after calculation.

\section{ACKNOWLEDGEMENTS}

W. Shotyk (University of Heidelberg) is warmly thanked for having borrowed us his Titanium Wardenaar corer and for having let us using the peat-cutting facilities at the IES (University of Heidelberg, Germany). This research was funded through the ATIS ('Absolute Time Scales and Isotope Studies for Investigating Events in Earth and Human History') Marie Curie Transfer of Knowledge project MTKD-CT-2005-029642. We thank William Marshall and one anonymous reviewer for the useful comments made on an earlier version of this manuscript.

\section{REFERENCES}

Ali AA, Ghaleb B, Garneau M, Asnong H and Loisel J, 2008. Recent peat accumulation rates in minerotrophic peatlands of the Bay James region, Eastern Canada, inferred by ${ }^{210} \mathrm{~Pb}$ and ${ }^{137} \mathrm{Cs}$ radiometric techniques. Applied Radiation and Isotopes 66(10): 13501358, DOI 10.1016/j.apradiso.2008.02.091.

Appleby PG. 2001. Chronostratigraphic techniques in recent sediments. In: Smol JP, Birks HJ and Last WM ,Eds., Tracking environmental change using lake sediments, volume 1: Basin analysis, coring and chronological techniques. Springer: 171-203, DOI 10.1016/S0341-8162(78)80002-2

Appleby PG and Oldfield F, 1978. The calculation of ${ }^{210} \mathrm{~Pb}$ dates assuming a constant rate of supply of unsupported ${ }^{210} \mathrm{~Pb}$ to the sediment. Catena 5:1-8, DOI 10.1016/S0341-8162(78)80002-2.

Appleby PG, Shotyk W and Frankhauser A, 1997. ${ }^{210} \mathrm{~Pb}$ age dating of three peat cores in the Jura Mountains, Switzerland. Water, Air and Soil Pollution 100: 223-231, DOI 10.1023/A:1018380922280.

Belokopytov IE and Beresnevich VV, 1955. Giktorf's peat borers. Torfanaa promislenost 8: 9-10.

Carroll J and Lerche I, 2003. Sedimentary Processes: Quantification Using Radionuclides, Elsevier, Amsterdam, pp 269.

De Vleeschouwer F, Gérard L, Goormaghtigh C, Mattielli N, Le Roux $\mathrm{G}$ and Fagel N, 2007. Atmospheric lead and heavy metal pollution records from a Belgian peat bog spaning the last two millennia: Human impact on a regional to global scale. The Science of The Total Environment 377(2-3): 282-295, DOI 10.1016/j.scitotenv.2007.02.017.

De Vleeschouwer F, Piotrowska N, Sikorski J, Pawlyta J, Cheburkin AK, Le Roux G, Lamentowicz M, Fagel N and Mauquoy D, 2009. Multiproxy evidence of 'Little Ice Age' palaeoenvironmental changes in a peat bog from northern Poland. The Holocene 19: 625-637, DOI 10.1177/0959683609104027

Ebaid YY and Khater AEM, 2006. Determination of ${ }^{210} \mathrm{~Pb}$ in environmental samples. Journal of Radioanalytical and Nuclear Chemistry 270: 609-619, DOI 10.1007/s10967-006-0470-5. 
Edgington DN and Robbins JA, 1975. Determination of the activity of lead-210 in sediments and soils. In : Lake Michigan Mass Balance Study, Volume 3-Metals, conventionals, radiochemistry and biomonitoring sample analysis techniques. Availlable online at www.epa.gov/greatlakes/lmmb/methods

El-Daoushy F, Olson K and Garcio-Tenorio R, 1991. Accuracies in Po210 determination for lead-210 dating. Hydrobiologia 214: 43-52, DOI 10.1007/BF00050930.

Erlinger $\mathrm{CH}$, Lettner H, Hubmer A, Hofmann W and Steinhäusler F, 2008. Determining the Chernobyl impact on sediments of a preAlpine lake with a very comprehensive set of data. Journal of Environmental Radioactivity 99(8): 1294-1301, DOI 0.1016/j.jenvrad.2008.03.012.

Fiałkiewicz-Kozieł B, 2009. Dynamika zmian zanieczyszczenia metalami ciężkimi na przykładzie wybranych torfowisk wysokich Kotliny Orawsko - Nowotarskiej (Dynamic of heavy metals concentrations in ombrotrophic peat bogs of the Orawa-Nowy Targ Basin). PhD thesis, University of Silesia Katowice, Poland: 169pp (in Polish).

Figgins PE, 1961. The radiochemistry ot Polonium. National Academy of Sciences-National Research Council-Nuclear Science Series 3037, Washington, USA: 74pp.

Flynn WW, 1968. The determination of low levels of ${ }^{210} \mathrm{Po}$ in environmental materials. Analytica Chimica Acta 43: 221-227, DOI 10.1016/S0003-2670(00)89210-7.

Gąsiorowski M and Hercman H, 2003. Recent changes of sedimentation rate in three vistula oxbow lakes determined by ${ }^{210} \mathrm{~Pb}$ dating. Geochronometria 24: 33-39.

Goslar T, Ganowicz M, Czernik J and Sikorski J, 2000. First measurements of natural radioactivities of ${ }^{210} \mathrm{~Pb}$ in the Insitute of Physics, Silesian University of Technology. Geochronometria 18: 29-34.

Holynska B, Ostachowicz B, Ostachowicz J, Samek L, Wachniew P, Obidowicz A, Wobrauschek P, Streli C and Halmetschlager G, 1998. Characterisation of ${ }^{210} \mathrm{~Pb}$ dated peat core by various $\mathrm{X}$-ray fluorescence techniques. The Science of the Total Environment 218: 239-248, DOI 10.1016/S0048-9697(98)00211-3.

Jia $\mathrm{G}$ and Torri G, 2007. Determination of ${ }^{210} \mathrm{~Pb}$ and ${ }^{210} \mathrm{Po}$ in soil or rock samples containig refractory matrices. Applied Radiation and Isotopes 65: 1-8, DOI 10.1016/j.apradiso.2006.05.007.

Jia G, Belli M, Blasi M, Marchetti A, Rosamilia S and Sansone U, 2001. Determination of ${ }^{210} \mathrm{~Pb}$ and ${ }^{210} \mathrm{Po}$ in mineral and biological environmental samples. Journal of Radioanalytical and Nuclear Chemistry 247: 491-499, DOI 10.1023/A:1010605804815.

Klaminder J, Yoo K and Giesler R, 2009. Soil carbon accumulation in the dry tundra: Important role played by precipitation. Journal of Geophysical Research 114: 4005-4014, DOI 10.1029/2009JG000947.

Krishnaswami S, Lal D, Martin JM and Meybeck M, 1971. Geochronology of lake sediments. Earth and Planetary Science Letters 11: 407-414, DOI 10.1016/0012-821X(71)90202-0.

Kylander ME, Weiss DJ, Jeffries T and Cole BJ, 2004. Sample preparation procedures for accurate and precise isotope analysis of $\mathrm{Pb}$ in peat by multiple collector (MC)-ICP-MS. Journal of Analytical Atomic Spectrometry 19: 1275-1277, DOI 10.1039/b406918h.

Lamentowicz M, Cedro A, Gałka M, Goslar T, Miotk-Szpiganowicz G, Mitchell EAD and Pawlyta J, 2008. Last millennium palaeoenvironmental changes from a Baltic bog (Poland) inferred from stable isotopes, pollen, plant macrofossils and testate amoebae. Palaeogeography, Palaeoclimatology, Palaeoecology 265(1-2): 93-106, DOI 10.1016/j.palaeo.2008.04.023.

Lamentowicz M, Milecka K, Galka M, Cedro A, Pawlyta J, Piotrowska N, Lamentowicz L and van der Knaap WO, 2009. Climate- and human-induced hydrological change since AD 800 in an ombrotrophic mire in Pomerania (N Poland) tracked by testate amoebae, macro-fossils, pollen, and tree-rings of pine. Boreas 38: 214-229, DOI 10.1111/j.1502-3885.2008.00047.x.

Le Roux G, Aubert D, Stille P, Krachler M, Kober B, Cheburkin A, Bonani G and Shotyk W, 2005. Recent atmospheric Pb deposition at a rural site in southern Germany assessed using a peat core and snowpack, and comparison with other archives. Atmospheric Environment 39(36): 6790-6801,

DOI 10.1016/j.atmosenv.2005.07.026

Luque JA and Julià R, 2002. Lake sediment response to land-use and climate change during the last 1000 years in the oligotrophic Lake Sanabria (northwest of Iberian Peninsula). Sedimentary Geology 148(1-2): 343-355, DOI 10.1016/S0037-0738(01)00225-1.

Martinez-Cortizas A, Garcia-Rodeja E, Pontevedra-Pombal X, Nóvoa Munoz J, Weiss D and Cheburkin A, 2002. Atmospheric Pb depo- sition in Spain during the last 4600 years recorded by two ombrotrophic peat bogs and implications for the use of peat as archive. The Science of the Total Environment 292: 33-44, DOI 10.1016/S0048-9697(02)00031-1.

Mizugaki S, Nakamura F and Araya T, 2006. Using dendrogeomorphology and ${ }^{137} \mathrm{Cs}$ and ${ }^{210} \mathrm{~Pb}$ radiochronology to estimate recent changes in sedimentation rates in Kushiro Mire, Northern Japan, resulting from land use change and river channelization. CATENA 68(1): 25-40, DOI 10.1016/j.catena.2006.03.014

Novak M, Erel Y, Zemanova L, Bottrell SH and Adamova M, 2008. A comparison of lead pollution record in Sphagnum peat with known historical $\mathrm{Pb}$ emission rates in the British Isles and the Czech Republic. Atmospheric Environment 42: 8997-9006, DOI 10.1016/j.atmosenv.2008.09.031.

Oldfield $\mathrm{F}$ and Appleby PG, 1984. Empirical testing of ${ }^{210} \mathrm{~Pb}$ dating models for lake sediments. In: Haworth EY and Lund JWG ,eds., Lake Sediments and Environmental History. Leic.Univ. Press: 93-124.

Olid C, Garcia-Orellana J, Martinez-Cortizas A, Masqué P, Peiteado E and Sanchez-Cabeza J-A, 2008. Role of surface vegetation in ${ }^{210} \mathrm{~Pb}$-dating of peat cores. Environmental Science and Technology 42: 8858-8864, DOI 10.1021/es801552v.

Persh F, 1950. Zur postglazialen Wald-und Moorentwicklung im Hohen Venn (About the post-glacial evolution of forests and peatlands in the Hohes Venn). Decheniana 104: 81-93 (in German).

Robbins JA, 1978. Geochemical and geophysical applications of radioactive lead. In: Nriagu JO ,ed., The biogeochemistry of lead in the environment. Elsevier, North Holland: 285-393.

Shotyk W, Weiss D, Appleby PG, Cheburkin AK, Frei R, Gloor M, Kramers JD, Reese S and Van Der Knaap WO, 1998. History of atmospheric lead deposition since $12,37014 \mathrm{C}$ yr BP from a peat bog, Jura mountains, Switzerland. Science 281: 1635-1640, DOI 10.1126/science.281.5383.1635.

Sikorski J, 2003. Rekonstrukcja historii depozycji osadów w zbiorniku wodnym Kozłowa Góra na podstawie pomiarów izotopu ołowiu ${ }^{210} \mathrm{~Pb}$ (The reconstruction of the deposition history of the water reservoir Kozłowa Góra on the basis of ${ }^{210} \mathrm{~Pb}$ activity measurements). $\mathrm{PhD}$ Thesis, Silesian University of Technology: 75-78 (in Polish).

Sikorski J and Bluszcz A, 2008. Application of $\alpha$ and $\gamma$ spectrometry in the ${ }^{210} \mathrm{~Pb}$ method to model sedimentation in artificial retention reservoir. Geochronometria 31: 65-75, DOI 10.2478/v10003-008 0019-4.

Sikorski J and Goslar T, 2003. Inventory of sediments of the dammed lake in Kozłowa Góra and first measurements of ${ }^{210} \mathrm{~Pb}$ activities in the lake deposits. Geochronometria 22: 55-62.

Tobin MJ and Schell WR, 1988. Recent developments sedimentation modeling and the statistical reliability of ${ }^{210} \mathrm{~Pb}$ dating method. $\mathrm{Ma}$ terials of Trace Models in Lakes Conference. The Master University Canada, Ontario: 1-23.

Turekian KK, Nozaki Y and Benninger LK, 1977. Geochemistry of Atmospheric Radon and Radon Products. Annual Review of Earth and Planetary Sciences 5: 227-255, DOI 10.1146/annurev.ea.05.050177.001303

Turetsky MR, Manning SW and Wieder R, 2004. Dating recent peat deposits. Wetlands 24: 324-356, DOI 10.1672/02775212(2004)024[0324:DRPD]2.0.CO;2.

Tylman W, 2003. Estimating recent sedimentation rates using ${ }^{210} \mathrm{~Pb}$ on the example of morphologically complex lake (upper lake Raduńskie, N Poland). Geochronometria 23: 21-26.

Vile MA, Wieder RK and Novak M, 1999. Mobility of Pb in Sphagnum-derived peat. Biogeochemistry 45: 35-5, DOI 10.1007/BF00992872.

Wardenaar ECP, 1987. A new handtool for cutting soil monoliths. Canadian Journal of Soil Sciences 67: 405-407, DOI 10.4141/cjss87-036.

Wastiaux C and Schumacker R, 2003. Topographie de surface et de subsurface des zones tourbeuses des réserves naturelles domaniales des Hautes-Fagnes (Surface and subsurface topography of peatlands from the Hautes-Fagnes Natural Reserve). Convention C60 entre le Ministère de la Région Wallonne, Direction générale des Ressources naturelles et de l'Environnement, et l'Université de Liège. Unpublished report: 52 $\mathrm{pp}+$ annexes. (in French)

Xiang L, Lu XX, Higgitt DL and Wang SM, 2002. Recent lake sedimentation in the middle and lower Yangtze basin inferred from ${ }^{137} \mathrm{Cs}$ and ${ }^{210} \mathrm{~Pb}$ measurements. Journal of Asian Earth Sciences 21(1): 77-86, DOI 10.1016/S1367-9120(02)00015-9. 